\title{
Important Factors Drive to Brand Image of Superstore Retail Organization: An Empirical Study on Shwapno
}

\author{
Azmat Ullah* Tanvir Morshad Kiash Iftekhar Kaiser Shimul \\ Department of Business Administration, Port City International University
}

\begin{abstract}
Superstore retail organization is the popular in the world as well as Bangladesh. High and mid classes' citizen in urban area are preferred for shopping any groceries products from superstore. Shwapno is the largest growing super chain shop in Bangladesh that provides all necessary commodities to the customers. This study is identified the factors which influence to the brand image and it drives to corporate image by providing perceived quality of products and services. The study has suggested top-level managers and authorities of Shwapno retail organization to consider these vital factors while enhancing brand image and leads to corporate image and aid to design the policies for retaining and satisfying their customers.
\end{abstract}

Keywords: Brand Image; Shwapno; Superstore; Corporate Image; Customers Attitude

DOI: $10.7176 / \mathrm{JPID} / 61-02$

Publication date: January $31^{\text {st }} 2022$

\section{Introduction}

There are various retail superstores in Bangladesh from them Shwapno is the top retail brand which is operated by ACI Logistics Limited. As the largest retail chain, Shwapno touches the lives of over 35,000 families per day. Customer satisfaction gives an indication of how much successfully the organization is meeting the demands of customers. The retail chain stores activities are directed towards customer satisfaction is the crucial factor for business growth that is leads to customer retention (S M Sohel Rana et al, 2014).

Super markets are not new business chain stores in Bangladesh. These shops are located in big cities of Bangladesh like Dhaka, Chittagong, Khulna, Rajshahi etc. The market is disbursed in such a way so that products are arranged according to their specialty and categories. In general shop, customers have no access to see the product but in super markets customers can see and collect the products for buying. They also can check the products before selecting them for buying. The decorations of the super markets are very much lucrative and attractive so that customers feel comfort to buy the product. Brand portfolios are helped to the customers for choosing their suited products from several branded products in one platform.

Objectives of the study

On the basis of significance of this study, the researchers are motivated to set up the following objectives:

(a) To overview the respondent demographics profiles of Shwapno retail superstore in Bangladesh.

(b) To evaluate the leading factors stimulated to brand image of Shwapno retail superstore in Bangladesh.

\section{Literature Review \\ Brand Image}

Brand image is the perceived performance of brand functional and extrinsic characteristics that a consumer attaches to a specific brand. Brand image indicate technical factors, social likability, product features or economic value (Nöth, 1988). Brand image refers to the total of impressions that the consumer takes up from different ways (Herzog, 1963). Brand image can help to create effective and efficient communication with consumers and it uncover the importance of brand identity (While Kapferer, 2003). Consumers are known to the brand image that can aid companies to host its new brand and pick up the sales of existing brands (Burt and Davies, 2010; Diallo et al., 2013; Martenson, 2007; Wu et al., 2011). Consumers' use of the brand to indicate their symbolic meaning of consumption and uniformity in self-expression is representing the brand image (Lau and Phau, 2007). Consumers' needs are satisfied into three dimensions of brand: functional benefits, symbolic benefits, and experiential benefits (Park et al., 1986). Brand image create differences among brands and it helps to occupy a distinct and favorable position in the customers mind. Product quality, product price, convenient location, promotional campaign, credit card facility, personnel services, physical aspect, and store environment are directly or indirectly helped to develop the brand image. The above mentioned factors are contributed the degree of customer satisfaction about Shwapno superstores retail in Bangladesh that are lead to brand image.

\section{Corporate Image}

Corporate image is intangible properties that help to bust up company's reputation and/or goodwill. The corporate image was an idea from the interaction between the Institute, staff, subscribers and communities (Walters, 1978) and there was an association with the capability of the organization to establish itself within the mind of the customer (LeBlanc and Nguyen, 1997). The image is important from two sides for corporate activities. One of them is, providing the information needed to strengthen and maintain the difference; the second is important for 
the company's durability. Every organization can have an image and in order to make this image positive, he must be involved in various activities to increase the quality of this image (Okay, 2005: 242). Keller (1998) also recognized credibility as a reason contributing to an overall image of an organization. Previous studies have found that there is significant impact on the corporate content of customer satisfaction and customer loyalty (Abdullah et al., 2000; Park et al., 2004; Chang and Tu, 2005; Martenson, 2007).

\section{Supermarket}

Super market is a latest and special insertion with the retail stores of Bangladesh. Bangladeshi supermarket sector has taken a steady growth in the country since the formation of Agora's journey in 2001. LightCastle Blog (2015) Stated that the super market domestic industry now stands at around BDT 1,500 crore. In one research Azad et.al (2012) conducted that since 1990s, like other developing countries of the world supermarket concept has been spread out in Bangladesh. However, it has got international form after 2010. Currently, there are almost 120 plus supermarkets in the country which is substantially controlled by three major players - Shwapno, Agora, Meena Bazar and Nandan (BSOA-Business Supermarkets Owners' Association). All the following advantages including per capital raise and urbanization are expediting this industry's profitability and growth because of the shift income of Bangladeshi people towards the middle income status. With rapid urbanization, super market industry of Bangladesh is anticipated to grow by almost 15 times of its current size by 2021. Positive economic externalities such as, generation of employment through SMEs, high food safety and security, price stability, and inclusive business development are expected to accompany this growth and development process. Because of the increasing demand of super markets, the satisfaction of the customers became an important issue to the entrepreneurs in this industry.

Jeevananda (2011) has stated Super markets are comes in different form and sizes and those are also called specialty stores, department stores, retail stores, superstore, super shop, discount stores, convenience stores and off price stores. Some of the prominent super markets of Bangladesh are Shwapno (59 Outlets), Agora (13 Outlets) and Meena Bazar (18 Outlets) Nandan Mega Shop, Almas General Stores, Al-Amin, Shop and Save, H.N.P. Family Mart, Khulshi Mart, Pick \& Pay Supermarket, Plaza central, Dash Department, BAFWA Complex, CSD, Basket, DCC Supermarket, Sanmar Complex and Plaza Center.

\section{Shwapno}

Shwapno retail brand was officially launched in 2008. Shwapno is the top retail brand in Bangladesh. As the largest retail chain in the country, Shwapno has been successful in reaching its position as market leader with $45 \%$ market share not only because of the exceptional quality, value, convenience and service it offers customers, but because Shwapno has been successful in developing a truly world class retail architecture and shopping experience for the first time in the country. Shwapno was initially focused on the price sensitive customer base, but after years of steady growth of its conventional retail and other channels, the company now serves a diverse market covering many segments. The Shwapno brand itself has evolved over this journey, and today is shifting its focus from value to nurturing aspiration. By delivering excellent service and through award winning communication campaigns, Shwapno has become the most recognized and trusted retail name in the country an achievement that was reflected with the awarding of the best retail brand award by Bangladesh Brand Forum in 2016. With 600,000 registered customers, 2500 colleagues, and thousands of suppliers and growers, Shwapno has a large footprint across the country. While continuing to expand its primary retail operations, raising standards and customers' expectations, as well as exploring new frontiers such as E-commerce, the company is well set to become one of Bangladesh's largest businesses in the coming years (www.aci-bd.com).

\section{Methodology}

It is descriptive research which is designed to find out important factors driving to brand image of Shwapno retail organization. Therefore, this study is helped to verify the competent factors leading to the brand reputation as well as customer satisfaction on Shwapno retail superstore in Bangladesh.

\section{Sample}

This study has been used non-probability convenient sampling procedure for collecting sample date. The closed ended questionnaire has been employed during August 2019 to February 2020 for collecting data and total numbers of sample are 120. Primary data has been collected from the several categories of customers on various outlets that are situated in different location at Chittagong metropolitan area in Bangladesh.

\section{Data Collection Technique}

This study basically depends on primary data gathering from a survey. For this reason a structured questionnaire has been developed. Excepting the questions relating to respondents demographic characteristics, the issues relating to customer satisfaction driving criteria like as product quality, product price, convenient location, promotional campaign, credit card facility, personnel services, physical aspect, and store environment, appraisal and investigated through 5-point Likert scale standardized by (Brayfield-Rothe, 1951). The scale makes up of 34 statements, for each statement has five options such as strongly agree $=5$, agree $=4$, undecided $=3$, disagree $=2$, and strongly disagree $=1$. 
Data Analysis Technique and Reliability of Scale

Statistical Package for Social Science (SPSS) software version 16 has been used for statistical analysis. Reliability of data has been evaluated by using the Cronbach Alpha (Cronbach, 1951). Cronbach Alpha was 0.806. Alpha is higher than 0.7 that is suggested by Nunnally (1978) data collection can be considered more reliable. There are 2 (two) segmentation in the questionnaire: The first section of the questionnaire is demographic information which encompasses age, education, profession, gender, marital status, purchasing type, purchasing frequencies, and amount of expenses etc. The second part contained 34 (thirty-four) items aimed at evaluating, builds for corporate reputation and brand image as well as customer satisfaction level in Shwapno retail superstore as recommended in the literature. Descriptive statistical techniques such as mean, frequency and percentage applied for understanding respondent's profile. Multiple regression models were employed to identify the factors those are significantly contributed to brand image.

4. Analysis and Findings:

Table: 1. Respondents Profiles

\begin{tabular}{|c|c|c|c|c|}
\hline & & Frequency & Valid Percent & Cumulative Percent \\
\hline Respondent Name & & 120 & 100.0 & 100.0 \\
\hline \multirow{5}{*}{ Age } & Bellow 20 years & 12 & 10.0 & 10.0 \\
\hline & $20-30$ years & 65 & 54.2 & 64.2 \\
\hline & $30-40$ years & 28 & 23.3 & 87.5 \\
\hline & Above 40 years & 15 & 12.5 & 100.0 \\
\hline & Total & 120 & 100.0 & \\
\hline \multirow{8}{*}{ Education } & Bellow SSC & 2 & 1.7 & 1.7 \\
\hline & $\mathrm{SSC}$ & 8 & 6.7 & 8.3 \\
\hline & $\mathrm{HSC}$ & 23 & 19.2 & 27.5 \\
\hline & Bachelor & 53 & 44.2 & 71.7 \\
\hline & Master & 23 & 19.2 & 90.8 \\
\hline & Ph.D & 2 & 1.7 & 92.5 \\
\hline & Others & 9 & 7.5 & 100.0 \\
\hline & Total & 120 & 100.0 & \\
\hline \multirow{7}{*}{ Profession } & Student & 40 & 33.3 & 33.3 \\
\hline & Housewife & 29 & 24.2 & 57.5 \\
\hline & Service Holder & 29 & 24.2 & 81.7 \\
\hline & Businessman & 18 & 15.0 & 96.7 \\
\hline & Retired & 3 & 2.5 & 99.2 \\
\hline & Others & 1 & .8 & 100.0 \\
\hline & Total & 120 & 100.0 & \\
\hline \multirow{3}{*}{ Gender } & Male & 76 & 63.3 & 63.3 \\
\hline & Female & 44 & 36.7 & 100.0 \\
\hline & Total & 120 & 100.0 & \\
\hline \multirow{3}{*}{ Marital Status } & Single & 61 & 50.8 & 50.8 \\
\hline & Married & 59 & 49.2 & 100.0 \\
\hline & Total & 120 & 100.0 & \\
\hline \multirow{3}{*}{ Purchasing Type } & First time purchase & 28 & 23.3 & 23.3 \\
\hline & Repeat purchase & 92 & 76.7 & 100.0 \\
\hline & Total & 120 & 100.0 & \\
\hline \multirow{4}{*}{ Frequency of Purchasing } & Daily & 6 & 5.0 & 5.0 \\
\hline & Weekly & 69 & 57.5 & 62.5 \\
\hline & Monthly & 45 & 37.5 & 100.0 \\
\hline & Total & 120 & 100.0 & \\
\hline \multirow{6}{*}{ Amount of Expenses } & Below1000 & 10 & 8.3 & 8.3 \\
\hline & $1000-2000$ & 24 & 20.0 & 28.3 \\
\hline & $2000-5000$ & 38 & 31.7 & 60.0 \\
\hline & $5000-10000$ & 41 & 34.2 & 94.2 \\
\hline & Above 10000 & 7 & 5.8 & 100.0 \\
\hline & Total & 120 & 100.0 & \\
\hline \multirow{3}{*}{ Credit Card Use } & Yes & 35 & 29.2 & 29.2 \\
\hline & No & 85 & 70.8 & 100.0 \\
\hline & Total & 120 & 100.0 & \\
\hline
\end{tabular}


The researcher surveyed 120 sample questions distributed to the respondents and among them 100 percent, respondents show their name. From above table revealed that 10 percent respondents age below 20 years, 54.2 percent respondent age 20-30 years, 23.3 percent people age 30-40 years, and 12.5 percent people age above 40 years. Among the respondents educational qualification overlook that 19.2 percent were HSC, 44.2 percent were bachelor, and 19.2 percent respondents were master degree that means maximum people have been highly educated. From demographic table researcher overlook that 33.3 percent people were students, 24.2 percent people were homemaker, 24.2 percent respondents were service holders, 15.0 percent people were businessman, 2.5 percent and 0.8 percent respondents were retired and others respectively. Total 76 respondents were male $(63.3 \%)$ and 44 respondents were female $(36.7 \%$ ) that means majority respondents were male who were frequently purchase groceries from Shwapno outlets. This study showed 57.5 percent respondents were weekly purchases and 34.2 percent peoples were spent TK.5000-TK.10000, 31.7 percent respondents were spent TK. 2000- TK. 5000. Among the respondents 70.8 percent people were used credit card when they have purchased product or services from Shwapno and rest 29.2 percent were cash payment.

Table: 2. Regression Results

\begin{tabular}{lcccc}
\hline \multicolumn{1}{c}{ Model } & Beta & T & Sig. \\
\hline Convenient Location & & .185 & 4.192 & .000 \\
Product Quality & & .331 & 7.202 & .000 \\
Credit Card Facility & .246 & 5.627 & .000 \\
Product Price & & .341 & 7.086 & .000 \\
Promotional Campaign & & .162 & 2.432 & .017 \\
Physical Aspect & & .108 & 1.710 & .090 \\
Personnel Service & & .126 & 1.722 & .088 \\
Store Environment & & .148 & 2.368 & .020 \\
\hline R Square & .805 & & & \\
Adjusted R Square & .791 & & & \\
F & 57.340 & & & \\
Significant F & 0.000 & & & \\
Durbin-Watson residuals correlation test & 1.932 & & & \\
\hline
\end{tabular}

a. Dependent Variable: Brand Image

b. Predictors (Constant): Store environment, credit card facility, convenient location, physical aspect, product quality, product price, promotional campaign, personnel service

Analysis of regression results revealed that relationship between separate variable and brand image that is significantly drive to firm image. Durbin-Watson residuals correlation test was 1.932 , which is acceptable range and significant correlation among all variable with brand image and organization reputation. The regression score showed that the $\mathrm{R}$ square and adjusted $\mathrm{R}$ square are 0.805 and 0.791 respectively. It explained with the relatively high coefficient of determination that is especially significant for brand image. The overall model disclosed that four variables out of eight dimensions indicated to be significant at $1 \%$ significance level with a positive beta and these factors are positive impact on brand image. Convenient location, product quality, credit card facility, and product price variables are influencing customer's satisfaction and satisfied customers will help to driven for enhancing the brand reputation. Promotional campaign and store environment of the retail superstores is also statistically significant at 0.05 level with a positive beta. This means that promotional campaign and store environment of retail superstores has significant positive effect on brand image. The physical aspect $(\operatorname{sig} t=0.090)$ and the personnel service ( $\operatorname{sig} \mathrm{t}=0.088)$ dimensions are not statistically significant at $5 \%$ significance level and in its direction negative towards corporate image that are not influenced customer satisfaction and brand image.

\section{Conclusions}

After analyzing this signifies that there was an adequate model because of the $\mathrm{F}$ value was high and significance level at 1 percent. Based on the result of principal component analysis and analysis of regression the researchers can conclude here brand image affected by customer's satisfactions which are depend on perceived quality of convenient location, product quality, credit card facility, product price, promotional campaign, physical aspect, personnel service, store environment. Shwapno retail superstores in Bangladesh should continuously increase the functional activities of their products or services to attract new customer and retain present customers. If Shwapno develop their brand image, it should be set up available physical outlet for providing smooth service to their current and prospect customers. Good employees services are needed in customers' point of view, so Shwapno improve their brand image have to have recruited and trained up their personnel for proving better sales services to the 
customers.

\section{References}

Abdullah M, Al-Nasser A, Husain N (2000). Evaluating functional relationship between image, customer satisfaction and customer loyalty using general maximum entropy. Total Qual. Manage., 11(6): 826-829.

Azad, S. N., Hossain, M. M., \& Parveen, R. (2012). Customer Perception, Price and Demand Analysis of Supermarkets in Dhaka City. Journal of Business and Technology (Dhaka), 6(2), 35-51

Brayfield, A. H., \& Rothe, H. F. (1951). An Index of Job Satisfaction. Journal of Applied Psychology, 35(5), pp.307-311.

Burt, S.L. and Davies, K. (2010), "From the retail brand to the retailer as a brand: themes and issues in retail branding research", International Journal of Retail \& Distribution Management, Vol. 38 Nos 11/12, pp. 865878.

Chang CH, Tu CY (2005). Exploring store image, customer satisfaction and customer loyalty relationship: evidence from Taiwanese hypermarket industry. J. Am. Acad. Bus., 7(2): 197-202.

Cronbach, L. J. (1951). Coefficient Alpha and Internal Structure of Test. Psychometrika, 16, 297-334.

Diallo, F.M., Chandon, J.L., Cliquet, G. and Philippe, J. (2013), "Factors influencing consumer behaviour towards store brands: evidence from the French market", International Journal of Retail \& Distribution Management, Vol. 41 No. 6, pp. 422-441.

Herzog, H. (1963). Behavioral science concepts for analyzing the consumer. Marketing and the Behavioral Sciences, 76-86.

https://www.aci-bd.com/our-businesses/retail-chain-shwapno.html

Jeevananda, Dr. S. (2011). A Study on Customer satisfaction level at Hypermarkets in Indian Retail Industry. Research Journal of Social Science \& Management, Vol. 1, Number 3.

Keller KL (1998). Strategic brand management: building, measuring and managing brand equity. Upper Saddle River. New Jersey: Prentice Hall.

Kapferer, J.N. The New Strategic Brand Management. London: Kogan Page, 2003

Lau, K.C. and Phau, I. (2007), "Extending symbolic brands using their personality: examining antecedents and implications towards brand image fit and brand dilution", Psychology and Marketing, Vol. 24 No. 5, pp. 421444.

LeBlanc G, Nguyen N (1997). Searching for excellence in business education: an exploratory study of customer impressions of service quality. Int. J. Educ. Manage., 11(2): 72-79.

LightCastle Blog.(2015).Business Insights. Website: http://www.lightcastlebd.com/blog/2015/02/market-insightsupermarket-industry- bangladesh

Martenson R (2007). Corporate brand image, satisfaction and store loyalty: a study of the store as a brand, store brands and manufacturer brands. Int. J. Retail. Distribut. Manage., 35(7): 544- 555

Nöth, W. (1988). The language of commodities Groundwork for a semiotics of consumer goods. International Journal of Research in Marketing, 4(3), 173-186. http://dx.doi.org/10.1016/S0167-8116(88)80003-X

Nunnally, J. L. (1978). Psychometric Theory. New York: McGraw Hill Company.

Okay, A. (2005). Kurum Kimliği, İstanbul: Mediacat Yayınları

Park, C.W., Jaworski, J.B. and Maclnnis, J.D. (1986), "Strategic brand concept-image management”, Journal of Marketing, Vol. 50, October, pp. 135-45.

Park J, Robertson R, Wu C (2004). The effect of airline service quality on passengers' behavioral intentions. $J$. Air Transp. Manage., 10:435-439

S M Sohel Rana, Abdullah Osman, \& Md. Aminul Islam (2014). Customer Satisfaction of Retail Chain Stores: Evidence from Bangladesh. Journal of Asian Scientific Research, 4(10): pp. 574-584.

Walters CG (1978). Consumer behavior: an integrated framework. New York: Richard D. Irwin

Wu, C.S., Yeh, G.Y.Y. and Hsiao, C.R. (2011), "The effect of store image and service quality on brand image and purchase intention for private label brands", Australasian Marketing Journal, Vol. 19 No. 1, pp. 30-39. 